\title{
Antiviral Compounds for Blocking Arboviral Transmission in Mosquitoes
}

\author{
Shengzhang Dong (D) and George Dimopoulos * \\ W. Harry Feinstone Department of Molecular Microbiology and Immunology, Bloomberg School of Public Health, \\ Johns Hopkins University, Baltimore, MD 21205, USA; sdong13@jhu.edu \\ * Correspondence: gdimopo1@jhu.edu; Tel.: +1-443-287-0128
}

check for

updates

Citation: Dong, S.; Dimopoulos, G. Antiviral Compounds for Blocking

Arboviral Transmission in

Mosquitoes. Viruses 2021, 13, 108.

https://doi.org/10.3390/v13010108

Academic Editors: Mariano

Agustin Garcia-Blanco,

October Sessions and Eng Eong Ooi

Received: 4 December 2020

Accepted: 11 January 2021

Published: 14 January 2021

Publisher's Note: MDPI stays neutral with regard to jurisdictional clai$\mathrm{ms}$ in published maps and institutional affiliations.

Copyright: (C) 2021 by the authors. Licensee MDPI, Basel, Switzerland. This article is an open access article distributed under the terms and conditions of the Creative Commons Attribution (CC BY) license (https:// creativecommons.org/licenses/by/ $4.0 /)$.

\begin{abstract}
Mosquito-borne arthropod-borne viruses (arboviruses) such as the dengue virus (DENV), Zika virus (ZIKV), and chikungunya virus (CHIKV) are important human pathogens that are responsible for significant global morbidity and mortality. The recent emergence and re-emergence of mosquito-borne viral diseases (MBVDs) highlight the urgent need for safe and effective vaccines, therapeutics, and vector-control approaches to prevent MBVD outbreaks. In nature, arboviruses circulate between vertebrate hosts and arthropod vectors; therefore, disrupting the virus lifecycle in mosquitoes is a major approach for combating MBVDs. Several strategies were proposed to render mosquitoes that are refractory to arboviral infection, for example, those involving the generation of genetically modified mosquitoes or infection with the symbiotic bacterium Wolbachia. Due to the recent development of high-throughput screening methods, an increasing number of drugs with inhibitory effects on mosquito-borne arboviruses in mammalian cells were identified. These antivirals are useful resources that can impede the circulation of arboviruses between arthropods and humans by either rendering viruses more vulnerable in humans or suppressing viral infection by reducing the expression of host factors in mosquitoes. In this review, we summarize recent advances in small-molecule antiarboviral drugs in mammalian and mosquito cells, and discuss how to use these antivirals to block the transmission of MBVDs.
\end{abstract}

Keywords: mosquito-borne viral diseases; antiviral drugs; small molecules; arboviral transmission cycle; dengue virus; Zika virus; Aedes aegypti

\section{Introduction}

Arthropod-borne viruses (arboviruses) are transmitted to humans or other vertebrates by arthropod vectors such as mosquitoes, ticks, and flies, and are mainly members of the Flaviviridae, Togaviridae, and Bunyaviridae families [1]. These viruses are transferred to a vertebrate host through saliva when an infected arthropod vector feeds on blood. There are more than 250 species of arboviruses, and at least 80 of them cause human diseases, including hemorrhagic fever, encephalitis, arthritis, and meningitis [2]. Diseases caused by arboviruses account for a major portion of vector-borne diseases (VBDs), and $80 \%$ of the global population lives in areas in which at least one VBD is endemic [3].

The recent emergence and re-emergence of mosquito-borne viral diseases (MBVDs) caused by, for example, the Zika virus (Flaviviridae, ZIKV), chikungunya virus (Togaviridae, CHIKV), dengue virus (Flaviviridae, DENV), Japanese encephalitis virus (Flaviviridae, JEV), West Nile virus (Flaviviridae, WNV), yellow fever virus (Flaviviridae, YFV) have raised international concerns, and continue to have a major impact on global public health and socioeconomic systems [4]. MBVDs are transmitted by culicine mosquitoes, mainly those in the Aedes and Culex genera. There are about 50 to 100 million infections by the four serotypes of DENV (DENV1 to DENV4) every year resulting in approximately 25,000 deaths [5]. CHIKV caused outbreaks in southern Europe in 2006-2007 and a small outbreak in the state of Florida, USA in 2014 [6,7]. The most recent ZIKV outbreak (2015-2016) in the 
Americas had a significant global effect on health and economic development [8]; during that outbreak, it was estimated that 1.5 million people had been infected in Brazil, with over 3500 cases of microcephaly reported.

Current control methods for MBVDs are insufficient because there is a lack of effective vaccines and medications to control key MBVDs (dengue, Zika, and chikungunya). Thus, novel control strategies are urgently needed to supplement traditional vector-control methods that still represent the main responses to most mosquito-borne diseases in endemic areas. A few novel control approaches have recently been proposed for the fight against MBVDs, including gene-drive-based mosquito population suppression and modification, and the release of Wolbachia-infected mosquitoes to either suppress or render mosquito populations refractory to the viral pathogens [9]. In this review, we summarize another control strategy relying on small-molecule antiviral compounds to block arboviral transmission in mosquitoes.

The arboviral transmission cycle in nature involves the circulation of the virus between vertebrate hosts and arthropod vectors. To establish a successful transmission cycle, an arbovirus needs to infect and replicate in cells of both vertebrates and arthropod vectors, and to reach a certain titer to render the mosquito infectious. One of the main approaches to impeding the transmission of MBVDs in nature is to suppress arboviral infection/replication in mosquitoes; this concept is supported by proof-of-principle studies using genetically modified mosquitoes that are refractory to arboviruses such as DENV and ZIKV [10-14]. Another novel approach is the use of antiviral compounds to inhibit arboviral infection in the vector [15].

In recent years, the rapid development of high-throughput screening methods has led to the discovery of a plethora of small-molecule compounds that can inhibit arboviral infection and/or replication in vertebrate cells [16-22], and a few also proved to be effective in mosquito cells. These anti-arboviral compounds can impede the circulation of arboviruses between arthropods and humans by either rendering arboviruses more vulnerable in humans or directly inhibiting viral infection and replication in mosquitoes. More importantly, most of these small-molecule drugs have already been approved by the Food and Drug Administration (FDA) or are currently evaluated in clinical trials. In this review, we mainly focus on current knowledge concerning the small-molecule compounds that can block the transmission of MBVDs between mosquitoes and humans, and the possible anti-arboviral mechanisms of these compounds in mosquitoes.

\section{Anti-Arboviral Compounds Suppressing Viral Infection in Mammalian Cells}

Small-molecule drugs are organic compounds of low molecular weight (usually under 900 Daltons) that regulate particular biochemical processes in ways that can result in the treatment or prevention of disease. Small-molecule drugs are attractive because they are easily synthesized due to their relatively low molecular weight and simple chemical structure, and they are generally highly stable [23]. By means of cell-based high-throughput screening, hundreds of small-molecule drugs were identified that can inhibit at least one type of arbovirus in mammalian cells [16-18,24-26]. In general, these screenings were mainly concentrated on DENV, and recently on ZIKV. These anti-arboviral drugs were derived from a diversity of sources, including plant products, bacterial metabolites, and chemically synthesized compounds. Some of the drugs exhibited a broad spectrum of antiarboviral activity in various mammalian cells in culture (Table 1) and in mice in vivo, but the antiviral nature of these drugs still needs to be further explored in mosquito biology. For example, nanchangmycin, a natural product of Streptomyces nanchangensis, can inhibit the production of several viruses in the Flaviviridae (DENV2, ZIKV, and WNV) and Togaviridae (SINV, CHIKV) families [27].

The modes of action of anti-arboviral drugs in mammalian cells are diverse, but they mainly target viral proteins and/or mammalian cell proteins to inhibit viral production, RNA synthesis, or entry, attachment, and secretion (Table 1). For example, sofosbuvir, an FDA-approved nucleotide polymerase inhibitor for the hepatitis $C$ virus, inhibited the 
RNA polymerase from various Flaviviridae family viruses, including ZIKV, DENV, and YFV [28-31], and interacted with CHIKV NsP4 to repress viral production [32]; suramin, an approved antiparasitic drug, blocked the replication of CHIKV by inhibiting an earlier post-attachment step in the CHIKV replicative cycle in vitro and viral RNA synthesis in vivo [33], suppressed ZIKV replication by interfering with the attachment and release of infectious progeny from host cells [34], and inhibited DENV production by interfering with attachment to host cells [35]. The diversified antiviral mechanisms of these drugs make it more difficult to develop drug resistance in host cells. This assertion was recently supported by a study showing that JG40 (an HSP70 inhibitor) had antiviral activity against a number of flaviviruses, including DENV2, WNV, and YFV, retaining a comparable inhibitory effect on DENV2 infection in mammalian cells (Huh-7) that were continuously treated for 10 passages [36].

Some antiviral drugs have a conserved mode of action on a number of different arboviruses in host cells. For example, niclosamide, an FDA-approved antiparasitic drug, inhibited the entry and transmission of DENV, CHIKV, and perhaps other viruses such as ZIKV by hindering endosomal acidification and interfering with $\mathrm{pH}$-dependent membrane fusion [37-40]. Drugs that exerted conserved antiviral mechanisms against multiple arboviruses in different mammalian cell types suggested that they may also have had a similar inhibitory effect in mosquito cells. This hypothesis is supported by recent studies that showed that 4-hydroxyphenyl retinamide (4-HPR) and mycophenolic acid (MPA), which inhibit pan-Flaviviridae arboviral infection in mammalian cells [41-44] also had a similar inhibitory effect on DENV2 and ZIKV infection in mosquito cells (C6/36) and mosquito (Ae. aegypti) midguts $[15,45]$. 
Table 1. Small-molecule compounds with a broad spectrum of antiarboviral activity in mammalian cells.

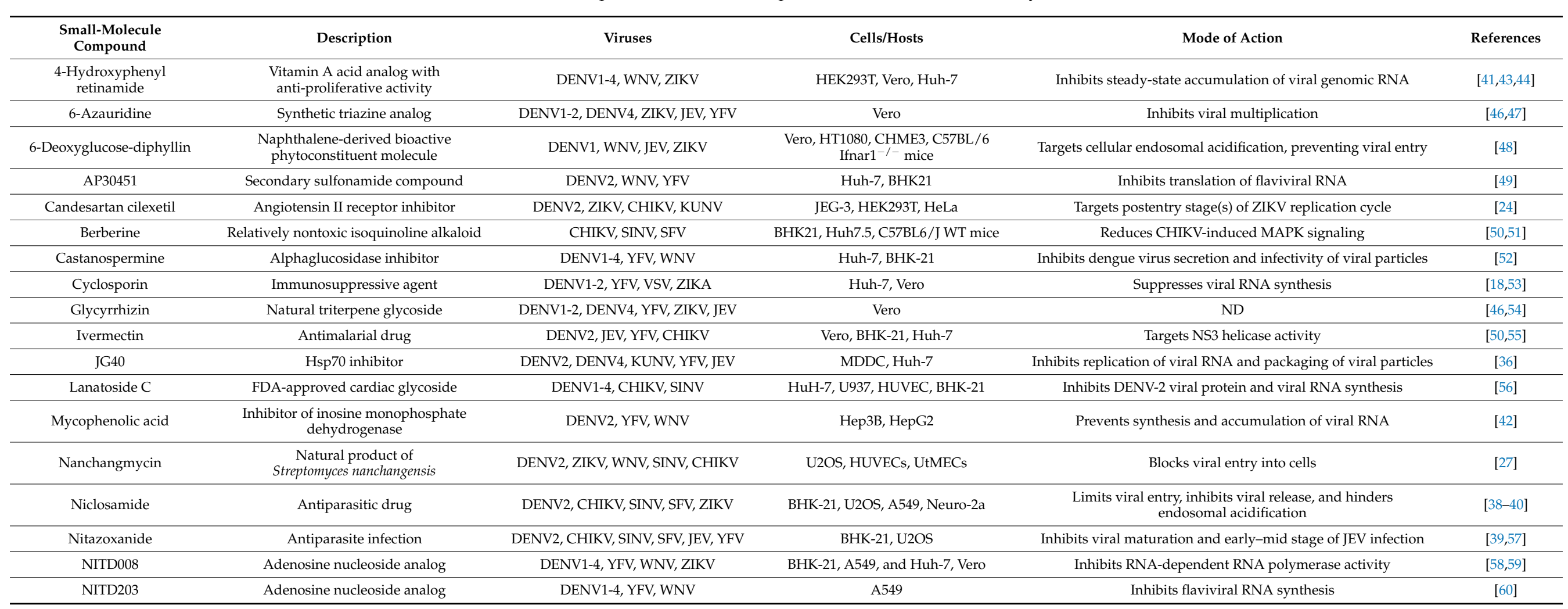


Table 1. Cont.

\begin{tabular}{|c|c|c|c|c|c|}
\hline $\begin{array}{l}\text { Small-Molecule } \\
\text { Compound }\end{array}$ & Description & Viruses & Cells/Hosts & Mode of Action & References \\
\hline $\begin{array}{c}\text { Orlistat } \\
\text { (tetrahydrolipstatin) }\end{array}$ & $\begin{array}{l}\text { FDA-approved drug used as } \\
\text { weight-loss medication }\end{array}$ & DENV1-4, ZIKV, CHIKV, JEV & HepG2, HEK293T & $\begin{array}{l}\text { Inhibits correct formation of DENV viral particles and release to } \\
\text { the cells }\end{array}$ & {$[61,62]$} \\
\hline Posaconazole & Potent antifungal drugs & DENV1-2, DENV4, ZIKV, YFV & Vero, BHK-21 & Inhibits RNA replication stage & [63] \\
\hline Quinestrol/raloxifene & Estrogen receptor modulators & DENV2, ZIKV, WNV (KUNV) & Huh-7, HTR8/SVneo & Inhibit viral RNA replication & [21] \\
\hline Ribavirin (RBV) & Broad-spectrum antiviral drug & DENV1-4, CHIKV, WNV, YFV & LLC-MK2, Hep3B, HepG2, Vero & Interferes with synthesis of DENV mRNA & {$[42,64-67]$} \\
\hline Sofosbuvir & Antihepatitis $C$ virus drug & DENV2, ZIKV, CHIKV, YFV & $\begin{array}{l}\text { HuH-7, HepG2, Vero, C57BL/6 mice, } \\
\text { A129-/-mice }\end{array}$ & $\begin{array}{c}\text { Inhibits DENV NS5 polymerase activity, targets CHIKV NsP4, } \\
\text { and reduces viral genome replication and infectious viral } \\
\text { particle production }\end{array}$ & [28-32] \\
\hline Tomatidine & Natural steroidal alkaloid & DENV1-4, ZIKV, CHIKV & A549, Huh-7 & Postentry step of viral replication cycle & {$[68,69]$} \\
\hline Valinomycin & Potassium-specific transporter & RVFV, LACV, ZIKV & Huh-7, Vero & Precludes viral replication by altering cellular potassium ions & [22] \\
\hline
\end{tabular}

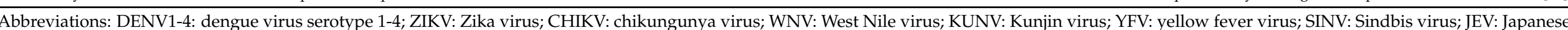
encephalitis virus; SFV: Semliki Forest virus; RVFV: Rift Valley fever virus; LACV: La Crosse virus; VSV: vesicular stomatitis virus. ND: not determined. 


\section{Antiarboviral Compounds Suppressing Virus Infection in Mosquito Cells}

As compared to mammalian cells, only a few small-molecule drugs were tested in mosquitoes or mosquito cells, and most of them represented already confirmed antiarbovirals in mammalian cells. To the best of our knowledge, there is no published high-throughput screening of small-molecule compounds for anti-arboviral activity in mosquito cells, while there is on Drosophila melanogaster cells [70,71].

The arboviral infection cycle in mosquito cells, like that in mammalian cells, involves an initial interaction between viral surface proteins and receptor molecules on the host cell surface, followed by receptor-mediated endocytosis to internalize the viral particles within the cytoplasm, viral assembly in the endoplasmic reticulum (ER), and lastly secretion of produced mature virions [72-74]. The arboviral infection cycle is the main target of smallmolecule compounds to suppress viral production in mosquito cells (Table 2). For example, chlorpromazine, monodanslycadervine, and dynasore are predicted inhibitors of receptormediated endocytosis that block clathrin-mediated endocytosis, which is part of viral entry into mosquito cells [75-77]. In fact, this is believed to be the main viral entry pathway for Flaviviridae arboviruses in mosquito cells [74]. In addition, an acidic $\mathrm{pH}$ compartment is required for viral infection of mosquito cells; therefore, small-molecule compounds that affect $\mathrm{pH}$ levels could inhibit viral production. This conjecture was supported when the production of DENV1-2 and WNV in C6/36 cells was shown to be inhibited by the addition of ammonium chloride to the cell medium during viral infection [72,76,77], and further studies revealed that ammonium chloride repressed viral replication by raising the $\mathrm{pH}$, thereby blocking the acidification of the endolysosomal network and the fusion of the viral envelope with endosomal membranes.

Table 2. Small-molecule compounds with anti-arboviral activity in mosquitoes and mosquito cells.

\begin{tabular}{|c|c|c|c|c|c|}
\hline $\begin{array}{l}\text { Small-Molecule } \\
\text { Compound }\end{array}$ & Description & Viruses & Cells/Hosts & Mode of Action & References \\
\hline $1 \mathrm{E} 7-03$ & Tetrahydroquinoline derivative & RFV & $\mathrm{C} 6 / 36$ & $\begin{array}{l}\text { Blocks viral RNA transcript/protein } \\
\text { interactions to inhibit viral RNA } \\
\text { production }\end{array}$ & [78] \\
\hline 2'C-methyladenosine & NS5 polymerase inhibitor & DENV2 & $\mathrm{C} 6 / 36$ & $\begin{array}{l}\text { Suppresses viral RNA synthesis and } \\
\text { viral protein expression }\end{array}$ & [36] \\
\hline $\begin{array}{l}\text { 4-Hydroxyphenyl } \\
\text { retinamide }\end{array}$ & $\begin{array}{l}\text { Vitamin A acid analog with } \\
\text { antiproliferative activity }\end{array}$ & DENV2, ZIKV & C6/36, Ae. aegypti & Targets ZIKV nonstructural protein 5 & {$[44,45]$} \\
\hline 5-Fluorouracil & $\begin{array}{l}\text { Potent antitumor agent; affects } \\
\text { pyrimidine synthesis. }\end{array}$ & DENV1, ZIKV & $\mathrm{C} 6 / 36$ & $\begin{array}{l}\text { Affects RNA incorporation into } \\
\text { DENV1 virions }\end{array}$ & {$[79,80]$} \\
\hline Ammonium chloride & Systemic and urinary acidifying salt & $\begin{array}{l}\text { DENV1-2, } \\
\text { WNV }\end{array}$ & $\mathrm{C} 6 / 36$ & $\begin{array}{l}\text { Influences fusion of viral envelope } \\
\text { with endosomal membrane }\end{array}$ & [75-77] \\
\hline Bafilomycin & $\begin{array}{l}\text { Macrolide antibiotic; inhibitor of } \\
\text { vacuolar } \mathrm{H}^{+} \text {-ATPase }\end{array}$ & DENV2, JEV & C6/36, Ae. aegypti & $\begin{array}{l}\text { Inhibits synthesis of } \\
\text { mosquito vATPase }\end{array}$ & {$[15,81]$} \\
\hline Benzodiazepine & Common type of antianxiety drug & YFV & $\mathrm{C} 6 / 36$ & $\begin{array}{l}\text { Inhibits postentry step of } \\
\text { YFV replication }\end{array}$ & {$[82]$} \\
\hline Bisindolymaleimide & Highly selective protein kinase C (PKC) & WNV & $\mathrm{C} 6 / 36$ & $\begin{array}{l}\text { Inhibits trafficking of internalized } \\
\text { WNV along the endosomal pathway }\end{array}$ & {$[75]$} \\
\hline Bortezomib & $\begin{array}{l}\text { Dipeptide boronic acid derivative and } \\
\text { proteasome inhibitor }\end{array}$ & ZIKV & C6/36, Ae. aegypti & Affects ZIKV entry process & {$[45,83]$} \\
\hline Chlorpromazine & $\begin{array}{l}\text { D2 dopamine receptor and } \mathrm{H} 1 \text { histamine } \\
\text { receptor antagonist }\end{array}$ & $\begin{array}{l}\text { DENV1-4, } \\
\text { WNV }\end{array}$ & $\mathrm{C} 6 / 36$ & $\begin{array}{l}\text { Blocks viral entry by inhibition of } \\
\text { clathrin-mediated endocytosis }\end{array}$ & [75-77] \\
\hline Clotrimazole & $\begin{array}{l}\text { Specific inhibitor of } \mathrm{Ca} 2+\text {-activated } \mathrm{K}+ \\
\text { channels. It is an antifungal azole }\end{array}$ & ZIKV & Ae. aegypti & ND & {$[45]$} \\
\hline Dansylcadaverine & Lysosomotropic agent & $\begin{array}{l}\text { DENV1-2, } \\
\text { WNV }\end{array}$ & $\mathrm{C} 6 / 36$ & $\begin{array}{l}\text { Inhibits clathrin-mediated } \\
\text { endocytosis }\end{array}$ & [75-77] \\
\hline Dynasore & Dynamin inhibitor & DENV2-4 & $\mathrm{C} 6 / 36$ & Blocks clathrin-mediated endocytosis & [76] \\
\hline
\end{tabular}


Table 2. Cont.

\begin{tabular}{|c|c|c|c|c|c|}
\hline $\begin{array}{l}\text { Small-Molecule } \\
\text { Compound }\end{array}$ & Description & Viruses & Cells/Hosts & Mode of Action & References \\
\hline Genistein & Multiple tyrosine kinase inhibitor & WNV & $\mathrm{C} 6 / 36$ & $\begin{array}{l}\text { Inhibits phosphorylation of focal } \\
\text { adhesion kinase }\end{array}$ & [75] \\
\hline Imatinib mesylate & $\begin{array}{l}\text { Known inhibitor of the c-Kit, Bcr-Abl, } \\
\text { and PDGFR tyrosine kinases }\end{array}$ & ZIKV & Ae. aegypti & ND & [45] \\
\hline Iota-carrageenan & Linear sulfated polysaccharide & DENV-2 & $\mathrm{C} 6 / 36$ & $\begin{array}{l}\text { Induces cell proliferation and reduces } \\
\text { protein synthesis }\end{array}$ & [84] \\
\hline MKT077/JG18/JG40 & Hsp70 inhibitors & DENV-2 & $\mathrm{C} 6 / 36$ & Inhibit viral RNA production & [36] \\
\hline Mycophenolic acid & $\begin{array}{l}\text { Non-nucleoside inhibitor of inosine } \\
\text { monophosphate dehydrogenase }\end{array}$ & DENV2, ZIKV & C6/36, Ae. aegypti & $\begin{array}{c}\text { Inhibits expression of } \\
\text { Inosine- } 5^{\prime} \text {-monophosphate } \\
\text { dehydrogenase in mosquitoes }\end{array}$ & {$[15,45,72]$} \\
\hline U18666A & $\begin{array}{l}\text { Intracellular cholesterol } \\
\text { transport inhibitor }\end{array}$ & ZIKV & Ae. aegypti & ND & [45] \\
\hline
\end{tabular}

Although mammalian and mosquito cells responded differently upon viral infection, some antiviral drugs employed a similar mode of action in both types of cells to inhibit arbovirus infection. For example, benzodiazepine inhibited YFV by targeting the viral NS4B protein in both human (HEK293 and Huh-7) and mosquito (C6/36) cells [82], and showed similar resistance profiles in NS4B mutants in these three cell types; 2 'C-methyladenosine and JG18 significantly reduced DENV2 production by suppressing viral RNA synthesis and viral protein expression in both mammalian (Huh-7) and mosquito (C6/36) cells [36]. However, most antiviral drugs have different modes of action with regard to arboviral infection in mammalian and mosquito cells. For instance, mycophenolic acid (MPA) inhibited the synthesis and accumulation of viral RNA (DENV2, YFV, and WNV) in various mammalian cells [42], whereas it suppressed DENV2 infection in Ae. aegypti midguts by reducing the expression of inosine-5'-monophosphate dehydrogenase (IMPDH) [15]. These distinct modes of action led to differences in the inhibitory activity of particular antiviral drugs in mammalian and mosquito cells. For instance, sulfated polysaccharides, including heparin, glucans, and carrageenans, were shown to be potent and selective inhibitors of arboviral infection in various mammalian cells [85-88], but they did not possess inhibitory effects in mosquito cells [89,90], likely because of a lack of adequate heparan sulfate (HS) in C6/36 cells; however, one particular type of sulfated polysaccharide, iota-carrageenan, did exhibit a moderate inhibitory effect on DENV2 infection in mosquito cells, although inhibition is weak when compared to that in mammalian cells [84]. This effect resulted from the antiviral activity that iota-carrageenan exerted during the initiation of replication in mammalian cells, thereby affecting DENV2 virion binding; in contrast, inhibitory activity in mosquito cells likely proceeded through the induction of cell proliferation and a reduction in protein synthesis [84].

\section{Anti-Arboviral Compounds with Mosquitocidal Activity}

Some anti-arboviral drugs possess both mosquitocidal and anti-arboviral activities in mosquito cells. For instance, ivermectin, a broad-spectrum antiparasitic agent, was demonstrated to have a toxic effect in C6/36 cells, and mosquitocidal activity in Aedes and Anopheles mosquitoes [45,91,92]. Ivermectin effectively inhibited infection with DENV2, JEV, YFV, and CHIKV in mammalian cells [50,55], but did not inhibit ZIKV in either mosquito cells or midguts when the concentration used for the assay was lower than the toxic level for cells or adult females was [45]. Cyclosporin, a broad-spectrum antiarboviral (effective against DENV1-2, YFV, VSV, and ZIKA) [18,53], did not inhibit ZIKV in C6/36 cells but exhibited strong larvicidal activity against Culex pipiens autogenicus [93], adulticidal activity against Ae. aegypti, and toxicity in C6/36 cells [45]. When compared to conventional insecticides, these anti-arboviral compounds were safe in humans, and mosquitoes have not developed resistance to any of them. Thus, they have great potential for the development of therapeutics that may also kill mosquitoes when they blood-feed. 


\section{Anti-Arboviral Drug Mechanisms in Mosquitoes}

When a mosquito ingests a viremic blood meal from an infected host, arboviruses are transferred to the mosquito midgut lumen, from where they infect epithelial cells; after replication, they are disseminated into the hemocoel. The viruses then infect and replicate in the salivary glands, and are released into the saliva, from which they can be transmitted to another host through a mosquito bite [94]. Thus, disrupting the arbovirus infection cycle in mosquitoes may be achieved by inhibiting viral infection/replication in midgut epithelial cells and salivary glands by either altering midgut microbiota or boosting the mosquitoes' antiviral immunity, targeting viral RNA with a small interfering RNA (siRNA) pathway, or functionally disrupting viral host factors. Theoretically, smallmolecule antiviral drugs could block the virus by interfering with any factors that are essential for viral infection/replication.

Small molecules that could enhance the mosquitoes' antiviral defense represent candidate anti-arboviral drugs. The systemic defense against arboviral infection in mosquitoes involves multiple tissue types, including the midgut, hemocytes, the central nervous system, and salivary glands $[95,96]$, and the innate immune response of mosquitoes is a key determinant of the successful transmission of arboviruses. Numerous studies showed that managing mosquitoes' innate immune pathways, such as the siRNA pathway [97,98], the Janus kinase-signal transducer and activator of transcription (JAK/STAT) pathway [10,99], and the Toll pathway [100], can reduce viral production and infection prevalence in Ae. aegypti mosquitoes. In addition to innate immunity, apoptosis also restricted arbovirus infection in mosquitoes, and induced apoptosis was shown to effectively reduce midgut infection, replication, and dissemination by SINV in Ae. aegypti [101]; furthermore, apoptosis limits WNV infection of midgut epithelial cells and the dissemination of virions from Culex pipiens pipiens midguts [102]. The retinoic acid (RA) derivative 4-HPR and a potential cancer-preventive agent that acts by inducing apoptosis in cancer cells, can inhibit ZIKV and DENV infection in mammalian cells [41,44] and mosquito midguts [45], and this inhibition likely occurs through an influence on apoptosis in the mosquitoes.

Small-molecule compounds that interfere with viral host factor (HFs) function have the potential to suppress viral infection or replication. HFs are mosquito factors that are essential for the infection and replication of an arbovirus in mosquito cells [95], and numerous HFs were recently identified in mosquitoes. For example, prohibitin was shown to be a DENV HF that can conceivably act as a receptor protein to mediate DENV entry into mosquito cells [103]; a saliva-specific protein, Ae. aegypti venom allergen-1 (AaVA-1), promotes DENV and ZIKV transmission in mammalian and mosquito cells [104]; and an Ae. aegypti C-type lectin, mosGCTL-1, interacts with WNV and facilitates infection in Ae. aegypti and Culex quinquefasciatus [105]. Thus, any small-molecule drugs that interfere with the expression or function of HFs in mosquitoes could hamper arboviral transmission between mosquitoes and humans. Moreover, some HFs are conserved between humans and mosquitoes. For example, vATPase plays a fundamental role in viral membrane fusion as a vacuolar proton pump that acidifies vacuoles [106], and the inhibition of vATPases with bafilomycin (BAF) was shown to suppress SINV and ZIKV infection in mammalian cells $[107,108]$ and JEV and DENV2 in mosquito cells, as well as DENV2 in Ae. aegypti midguts $[15,76]$.

\section{Application of Antiviral Compounds in Mosquitoes}

To block arboviruses in mosquitoes, antiviral drugs must be delivered to the adult stage, ideally in a way by which they could become exposed to the midgut tissue, which is the entry point and key replication site for arboviruses. Thus, these drugs could be implemented as part of attractive toxic sugar baits (ATSBs), a novel control approach that was recently employed for adult mosquito control in the field [109]. The concept exploited the sugar-feeding behavior of mosquitoes, inducing them to feed on artificial nectar containing an insecticidal ingredient. ATSBs could reduce mosquito populations and thus the probability of arboviral transmission; however, ATSBs also attracted and killed 
nontargeted beneficial insects such as honeybees and parasitoid wasps [110]. If insecticides were replaced with small-molecule antiviral drugs, the baits would be rendered more environmentally friendly, and the accidental killing of beneficial insects would be reduced. Thus, antiviral drugs could be considered as an alternative ingredient in ATSBs.

Insecticide-treated bed nets (ITNs) are effective in preventing VBDs, and they achieved great success in preventing malaria, which is mainly transmitted by Anopheles mosquitoes [111,112]. ITNs were also proved effective in controlling Aedes mosquitoes and reducing dengue virus prevalence $[113,114]$; however, resistance to widely used insecticides such as pyrethroids, organochlorines, and organophosphates developed in mosquito populations, rendering ITNs less effective for controlling VBDs. A recent study showed that using specific antimalarial drugs instead of insecticides can achieve similar transmissionblocking effects on Plasmodium in Anopheles mosquitoes [115]. Thus, the application of antiviral drugs to bed nets can be reasonably considered for blocking arboviral transmission in mosquitoes. For the safety of the environment and humans, small antiviral drugs could also be applied with indoor residual spraying (IRS) to prevent arboviral transmission.

\section{Future Prospects and Challenges}

The advantages of using small-molecule drugs to impede arboviral transmission are obvious: they are safe for both humans and the environment, and they can be transferred from humans to mosquitoes when patients receive treatment with the drugs; however, because of significant differences in drug metabolism and viral pathogenesis between vertebrates and insects, and the fact that mosquitoes lack adaptive immune responses and are dependent on innate immunity for defense against viral infection, many small-molecule anti-arboviral drugs that work in mammalian cells do not have a similarly inhibitory effect on arboviral infection/replication in mosquitoes and mosquito cells. It is challenging to identify anti-arboviral drugs that are effective in mosquitoes on the basis of the current pool of anti-arboviral drugs in mammalian cells. In addition, most small-molecule drugs are costly. Nevertheless, a few antiviral drugs have an inhibitory effect on arboviral infection in both mosquitoes and mosquito cells, demonstrating that it is possible to use antiviral compounds to stop the spread of VBDs in mosquitoes. Studies should focus on identifying small-molecule drugs with strong transmission-blocking activity against key arboviruses in mosquitoes. These drugs have advantages for therapeutic activity in mammals and transmission-blocking activity in mosquitos; thus, such dual-action drugs could limit the transmission of arboviruses from infected people who are being treated.

Funding: This work was supported by The National Institutes of Health (grant R01AI141532) and the Bloomberg Philanthropies.

Institutional Review Board Statement: Not applicable.

Informed Consent Statement: Not applicable.

Data Availability Statement: Not applicable.

Acknowledgments: We thank Deborah McClellan for the editorial assistance.

Conflicts of Interest: The authors declare no conflict of interest.

\section{References}

1. Weaver, S.C. Host range, amplification and arboviral disease emergence. Arch. Virol. Suppl. 2005, 19, 33-44.

2. Gaunt, M.W.; Sall, A.A.; Lamballerie, X.; Falconar, A.K.I.; Dzhivanian, T.I.; Gould, E.A. Phylogenetic relationships of flaviviruses correlate with their epidemiology, disease association and biogeography. J. Gen. Virol. 2001, 82, 1867-1876. [CrossRef] [PubMed]

3. WHO-World Health Organization. Evaluation of Genetically Modified Mosquitoes for the Control. of Vector-Borne Diseases; WHO: Geneva, Switzerland, 2020; p. 7.

4. Weaver, S.C.; Charlier, C.; Vasilakis, N.; Lecuit, M. Zika, Chikungunya, and Other Emerging Vector-Borne Viral Diseases. Annu. Rev. Med. 2018, 69, 395-408. [CrossRef] [PubMed] 
5. Stanaway, J.D.; Shepard, D.S.; Undurraga, E.A.; Halasa, Y.A.; Coffeng, L.E.; Brady, O.J.; Hay, S.I.; Bedi, N.; Bensenor, I.M.; Castaneda-Orjuela, C.A.; et al. The global burden of dengue: An analysis from the Global Burden of Disease Study 2013. Lancet Infect. Dis. 2016, 16, 712-723. [CrossRef]

6. Dong, S.; Kantor, A.M.; Lin, J.; Passarelli, A.L.; Clem, R.J.; Franz, A.W. Infection pattern and transmission potential of chikungunya virus in two New World laboratory-adapted Aedes aegypti strains. Sci. Rep. 2016, 6, 24729. [CrossRef] [PubMed]

7. Yactayo, S.; Staples, J.E.; Millot, V.; Cibrelus, L.; Ramon-Pardo, P. Epidemiology of Chikungunya in the Americas. J. Infect. Dis. 2016, 214 (Suppl. 5), S441-S445. [CrossRef]

8. Sikka, V.; Chattu, V.K.; Popli, R.K.; Galwankar, S.C.; Kelkar, D.; Sawicki, S.G.; Stawicki, S.P.; Papadimos, T.J. The emergence of zika virus as a global health security threat: A review and a consensus statement of the INDUSEM Joint working Group (JWG). J. Glob. Infect. Dis. 2016, 8, 3-15.

9. Caragata, E.P.; Dong, S.; Dong, Y.; Simoes, M.L.; Tikhe, C.V.; Dimopoulos, G. Prospects and Pitfalls: Next-Generation Tools to Control Mosquito-Transmitted Disease. Annu. Rev. Microbiol. 2020, 74, 455-475. [CrossRef]

10. Jupatanakul, N.; Sim, S.; Anglero-Rodriguez, Y.I.; Souza-Neto, J.; Das, S.; Poti, K.E.; Rossi, S.L.; Bergren, N.; Vasilakis, N.; Dimopoulos, G. Engineered Aedes aegypti JAK/STAT Pathway-Mediated Immunity to Dengue Virus. PLoS Negl. Trop. Dis. 2017, 11, e0005187. [CrossRef]

11. Buchman, A.; Gamez, S.; Li, M.; Antoshechkin, I.; Li, H.H.; Wang, H.W.; Chen, C.H.; Klein, M.J.; Duchemin, J.B.; Crowe, J.E., Jr; et al. Broad dengue neutralization in mosquitoes expressing an engineered antibody. PLoS Pathog. 2020, 16, e1008103. [CrossRef]

12. Buchman, A.; Gamez, S.; Li, M.; Antoshechkin, I.; Li, H.H.; Wang, H.W.; Chen, C.H.; Klein, M.J.; Duchemin, J.B.; Paradkar, P.N.; et al. Engineered resistance to Zika virus in transgenic Aedes aegypti expressing a polycistronic cluster of synthetic small RNAs. Proc. Natl. Acad. Sci. USA 2019, 116, 3656-3661. [CrossRef] [PubMed]

13. Franz, A.W.; Sanchez-Vargas, I.; Adelman, Z.N.; Blair, C.D.; Beaty, B.J.; James, A.A.; Olson, K.E. Engineering RNA interferencebased resistance to dengue virus type 2 in genetically modified Aedes aegypti. Proc. Natl. Acad. Sci. USA 2006, 103, 4198-4203. [CrossRef] [PubMed]

14. Williams, A.E.; Sanchez-Vargas, I.; Reid, W.R.; Lin, J.; Franz, A.W.E.; Olson, K.E. The Antiviral Small-Interfering RNA Pathway Induces Zika Virus Resistance in Transgenic Aedes aegypti. Viruses 2020, 12, 1231. [CrossRef]

15. Kang, S.; Shields, A.R.; Jupatanakul, N.; Dimopoulos, G. Suppressing dengue-2 infection by chemical inhibition of Aedes aegypti host factors. PLoS Negl. Trop. Dis. 2014, 8, e3084. [CrossRef]

16. Kato, F.; Nio, Y.; Yagasaki, K.; Suzuki, R.; Hijikata, M.; Miura, T.; Miyazaki, I.; Tajima, S.; Lim, C.K.; Saijo, M.; et al. Identification of inhibitors of dengue viral replication using replicon cells expressing secretory luciferase. Antivir. Res. 2019, $172,104643$. [CrossRef] [PubMed]

17. Morales Vasquez, D.; Park, J.G.; Avila-Perez, G.; Nogales, A.; de la Torre, J.C.; Almazan, F.; Martinez-Sobrido, L. Identification of Inhibitors of ZIKV Replication. Viruses 2020, 12, 1041. [CrossRef]

18. Barrows, N.J.; Campos, R.K.; Powell, S.T.; Prasanth, K.R.; Schott-Lerner, G.; Soto-Acosta, R.; Galarza-Munoz, G.; McGrath, E.L.; Urrabaz-Garza, R.; Gao, J.; et al. A Screen of FDA-Approved Drugs for Inhibitors of Zika Virus Infection. Cell Host Microbe 2016, 20, 259-270. [CrossRef]

19. Pitts, J.; Hsia, C.Y.; Lian, W.L.; Wang, J.H.; Pfeil, M.P.; Kwiatkowski, N.; Li, Z.N.; Jang, J.; Gray, N.S.; Yang, P.L. Identification of small molecule inhibitors targeting the Zika virus envelope protein. Antivir. Res. 2019, 164, 147-153. [CrossRef]

20. Zhang, Z.R.; Zhang, H.Q.; Li, X.D.; Deng, C.L.; Wang, Z.; Li, J.Q.; Li, N.; Zhang, Q.Y.; Zhang, H.L.; Zhang, B.; et al. Generation and characterization of Japanese encephalitis virus expressing GFP reporter gene for high throughput drug screening. Antivir. Res. 2020, 182, 104884. [CrossRef]

21. Eyre, N.S.; Kirby, E.N.; Anfiteatro, D.R.; Bracho, G.; Russo, A.G.; White, P.A.; Aloia, A.L.; Beard, M.R. Identification of Estrogen Receptor Modulators as inhibitors of Flavivirus Infection. Antimicrob. Agents Chemother. 2020, 64. [CrossRef]

22. Sandler, Z.J.; Firpo, M.R.; Omoba, O.S.; Vu, M.N.; Menachery, V.D.; Mounce, B.C. Novel Ionophores Active against La Crosse Virus Identified through Rapid Antiviral Screening. Antimicrob. Agents Chemother. 2020, 64. [CrossRef]

23. Samanen, J. Similarities and differences in the discovery and use of biopharmaceuticals and small-molecule chemotherapeutics. Introd. Biol. Small Mol. Drug Res. Dev. Theory Case Stud. 2013, 161-203. [CrossRef]

24. Loe, M.W.C.; Lee, R.C.H.; Chu, J.J.H. Antiviral activity of the FDA-approved drug candesartan cilexetil against Zika virus infection. Antivir. Res. 2019, 172, 104637. [CrossRef] [PubMed]

25. van Cleef, K.W.R.; Overheul, G.J.; Thomassen, M.C.; Kaptein, S.J.F.; Davidson, A.D.; Jacobs, M.; Neyts, J.; van Kuppeveld, F.J.M.; van Rij, R.P. Identification of a new dengue virus inhibitor that targets the viral NS4B protein and restricts genomic RNA replication. Antivir. Res. 2013, 99, 165-171. [CrossRef]

26. Balasubramanian, A.; Teramoto, T.; Kulkarni, A.A.; Bhattacharjee, A.K.; Padmanabhan, R. Antiviral activities of selected antimalarials against dengue virus type 2 and Zika virus. Antivir. Res. 2017, 137, 141-150. [CrossRef] [PubMed]

27. Rausch, K.; Hackett, B.A.; Weinbren, N.L.; Reeder, S.M.; Sadovsky, Y.; Hunter, C.A.; Schultz, D.C.; Coyne, C.B.; Cherry, S. Screening Bioactives Reveals Nanchangmycin as a Broad Spectrum Antiviral Active against Zika Virus. Cell Rep. 2017, 18, 804-815. [CrossRef]

28. Bullard-Feibelman, K.M.; Govero, J.; Zhu, Z.; Salazar, V.; Veselinovic, M.; Diamond, M.S.; Geiss, B.J. The FDA-approved drug sofosbuvir inhibits Zika virus infection. Antivir. Res. 2017, 137, 134-140. [CrossRef] 
29. de Freitas, C.S.; Higa, L.M.; Sacramento, C.Q.; Ferreira, A.C.; Reis, P.A.; Delvecchio, R.; Monteiro, F.L.; Barbosa-Lima, G.; Westgarth, H.J.; Vieira, Y.R.; et al. Yellow fever virus is susceptible to sofosbuvir both in vitro and in vivo. PLoS Negl. Trop. Dis. 2019, 13, e0007072. [CrossRef]

30. Gan, C.S.; Lim, S.K.; Chee, C.F.; Yusof, R.; Heh, C.H. Sofosbuvir as treatment against dengue? Chem. Biol. Drug. Des. 2018, 91, 448-455. [CrossRef]

31. Xu, H.T.; Colby-Germinario, S.P.; Hassounah, S.A.; Fogarty, C.; Osman, N.; Palanisamy, N.; Han, Y.S.; Oliveira, M.; Quan, Y.D.; Wainberg, M.A. Evaluation of Sofosbuvir (beta-D-2'-deoxy-2'-alpha-fluoro-2'-beta-C-methyluridine) as an inhibitor of Dengue virus replication. Sci. Rep. 2017, 7, 1-11.

32. Ferreira, A.C.; Reis, P.A.; de Freitas, C.S.; Sacramento, C.Q.; Hoelz, L.V.B.; Bastos, M.M.; Mattos, M.; Rocha, N.; Quintanilha, I.G.D.; Pedrosa, C.D.G.; et al. Beyond Members of the Flaviviridae Family, Sofosbuvir Also Inhibits Chikungunya Virus Replication. Antimicrob. Agents Chemother. 2019, 63. [CrossRef]

33. Albulescu, I.C.; van Hoolwerff, M.; Wolters, L.A.; Bottaro, E.; Nastruzzi, C.; Yang, S.C.; Tsay, S.C.; Hwu, J.R.; Snijder, E.J.; van Hemert, M.J. Suramin inhibits chikungunya virus replication through multiple mechanisms. Antivir. Res. 2015, 121, 39-46. [CrossRef] [PubMed]

34. Albulescu, I.C.; Kovacikova, K.; Tas, A.; Snijder, E.J.; van Hemert, M.J. Suramin inhibits Zika virus replication by interfering with virus attachment and release of infectious particles. Antivir. Res. 2017, 143, 230-236. [CrossRef] [PubMed]

35. Chen, Y.P.; Maguire, T.; Hileman, R.E.; Fromm, J.R.; Esko, J.D.; Linhardt, R.J.; Marks, R.M. Dengue virus infectivity depends on envelope protein binding to target cell heparan sulfate. Nat. Med. 1997, 3, 866-871. [CrossRef] [PubMed]

36. Taguwa, S.; Maringer, K.; Li, X.K.; Bernal-Rubio, D.; Rauch, J.N.; Gestwicki, J.E.; Andino, R.; Fernandez-Sesma, A.; Frydman, J. Defining Hsp70 Subnetworks in Dengue Virus Replication Reveals Key Vulnerability in Flavivirus Infection. Cell 2015, 163, 1108-1123. [CrossRef] [PubMed]

37. Jurgeit, A.; McDowell, R.; Moese, S.; Meldrum, E.; Schwendener, R.; Greber, U.F. Niclosamide Is a Proton Carrier and Targets Acidic Endosomes with Broad Antiviral Effects. PLoS Pathog. 2012, 8, e1002976. [CrossRef] [PubMed]

38. Kao, J.C.; HuangFu, W.C.; Tsai, T.T.; Ho, M.R.; Jhan, M.K.; Shen, T.J.; Tseng, P.C.; Wang, Y.T.; Lin, C.F. The antiparasitic drug niclosamide inhibits dengue virus infection by interfering with endosomal acidification independent of mTOR. PLoS Negl. Trop. Dis. 2018, 12, e0006715. [CrossRef] [PubMed]

39. Wang, Y.M.; Lu, J.W.; Lin, C.C.; Chin, Y.F.; Wu, T.Y.; Lin, L.I.; Lai, Z.Z.; Kuo, S.C.; Ho, Y.J. Antiviral activities of niclosamide and nitazoxanide against chikungunya virus entry and transmission. Antivir. Res. 2016, 135, 81-90. [CrossRef]

40. Xu, M.; Lee, E.M.; Wen, Z.; Cheng, Y.; Huang, W.K.; Qian, X.; Tcw, J.; Kouznetsova, J.; Ogden, S.C.; Hammack, C.; et al. Identification of small-molecule inhibitors of Zika virus infection and induced neural cell death via a drug repurposing screen. Nat. Med. 2016, 22, 1101-1107. [CrossRef]

41. Carocci, M.; Hinshaw, S.M.; Rodgers, M.A.; Villareal, V.A.; Burri, D.J.; Pilankatta, R.; Maharaj, N.P.; Gack, M.U.; Stavale, E.J.; Warfield, K.L.; et al. The bioactive lipid 4-hydroxyphenyl retinamide inhibits flavivirus replication. Antimicrob. Agents Chemother. 2015, 59, 85-95. [CrossRef]

42. Diamond, M.S.; Zachariah, M.; Harris, E. Mycophenolic acid inhibits dengue virus infection by preventing replication of viral RNA. Virology 2002, 304, 211-221. [CrossRef]

43. Fraser, J.E.; Watanabe, S.; Wang, C.X.; Chan, W.K.K.; Maher, B.; Lopez-Denman, A.; Hick, C.; Wagstaff, K.M.; Mackenzie, J.M.; Sexton, P.M.; et al. A nuclear transport inhibitor that modulates the unfolded protein response and provides in vivo protection against lethal dengue virus infection. J. Infect. Dis. 2014, 210, 1780-1791. [CrossRef] [PubMed]

44. Pitts, J.D.; Li, P.C.; de Wispelaere, M.; Yang, P.L. Antiviral activity of N-(4-hydroxyphenyl) retinamide (4-HPR) against Zika virus. Antivir. Res. 2017, 147, 124-130. [CrossRef] [PubMed]

45. Dong, S.; Kang, S.; Dimopoulos, G. Identification of anti-flaviviral drugs with mosquitocidal and anti-Zika virus activity in Aedes aegypti. PLoS Negl. Trop. Dis. 2019, 13, e0007681. [CrossRef]

46. Crance, J.M.; Scaramozzino, N.; Jouan, A.; Garin, D. Interferon, ribavirin, 6-azauridine and glycyrrhizin: Antiviral compounds active against pathogenic flaviviruses. Antivir. Res. 2003, 58, 73-79. [CrossRef]

47. Pascoalino, B.S.; Courtemanche, G.; Cordeiro, M.T.; Gil, L.H.; Freitas-Junior, L. Zika antiviral chemotherapy: Identification of drugs and promising starting points for drug discovery from an FDA-approved library. F1000Research 2016, 5, 2523. [CrossRef]

48. Martinez-Lopez, A.; Persaud, M.; Chavez, M.P.; Zhang, H.; Rong, L.; Liu, S.; Wang, T.T.; Sarafianos, S.G.; Diaz-Griffero, F. Glycosylated diphyllin as a broad-spectrum antiviral agent against Zika virus. EBioMedicine 2019, 47, 269-283. [CrossRef]

49. Noueiry, A.O.; Olivo, P.D.; Slomczynska, U.; Zhou, Y.; Buscher, B.; Geiss, B.; Engle, M.; Roth, R.M.; Chung, K.M.; Samuel, M.; et al. Identification of novel small-molecule inhibitors of West Nile virus infection. J. Virol. 2007, 81, 11992-12004. [CrossRef]

50. Varghese, F.S.; Kaukinen, P.; Glasker, S.; Bespalov, M.; Hanski, L.; Wennerberg, K.; Kummerer, B.M.; Ahola, T. Discovery of berberine, abamectin and ivermectin as antivirals against chikungunya and other alphaviruses. Antivir. Res. 2016, 126, 117-124. [CrossRef]

51. Varghese, F.S.; Thaa, B.; Amrun, S.N.; Simarmata, D.; Rausalu, K.; Nyman, T.A.; Merits, A.; McInerney, G.M.; Ng, L.F.P.; Ahola, T. The Antiviral Alkaloid Berberine Reduces Chikungunya Virus-Induced Mitogen-Activated Protein Kinase Signaling. J. Virol. 2016, 90, 9743-9757. [CrossRef]

52. Whitby, K.; Pierson, T.C.; Geiss, B.; Lane, K.; Engle, M.; Zhou, Y.; Doms, R.W.; Diamond, M.S. Castanospermine, a potent inhibitor of dengue virus infection in vitro and in vivo. J. Virol. 2005, 79, 8698-8706. [CrossRef] [PubMed] 
53. Qing, M.; Yang, F.; Zhang, B.; Zou, G.; Robida, J.M.; Yuan, Z.M.; Tang, H.L.; Shi, P.Y. Cyclosporine Inhibits Flavivirus Replication through Blocking the Interaction between Host Cyclophilins and Viral NS5 Protein. Antimicrob. Agents Chemother. 2009, 53, 3226-3235. [CrossRef]

54. Baltina, L.A.; Tasi, Y.T.; Huang, S.H.; Lai, H.C.; Lia, A.B.; Petrova, S.F.; Yunusov, M.S.; Lin, C.W. Glycyrrhizic acid derivatives as Dengue virus inhibitors. Bioorg. Med. Chem. Lett. 2019, 29, 126645. [CrossRef] [PubMed]

55. Mastrangelo, E.; Pezzullo, M.; De Burghgraeve, T.; Kaptein, S.; Pastorino, B.; Dallmeier, K.; de Lamballerie, X.; Neyts, J.; Hanson, A.M.; Frick, D.N.; et al. Ivermectin is a potent inhibitor of flavivirus replication specifically targeting NS3 helicase activity: New prospects for an old drug. J. Antimicrob. Chemoth. 2012, 67, 1884-1894. [CrossRef] [PubMed]

56. Cheung, Y.Y.; Chen, K.C.; Chen, H.X.; Seng, E.K.; Chu, J.J.H. Antiviral activity of lanatoside C against dengue virus infection. Antivir. Res. 2014, 111, 93-99. [CrossRef] [PubMed]

57. Shi, Z.; Wei, J.; Deng, X.; Li, S.; Qiu, Y.; Shao, D.; Li, B.; Zhang, K.; Xue, F.; Wang, X.; et al. Nitazoxanide inhibits the replication of Japanese encephalitis virus in cultured cells and in a mouse model. Virol. J. 2014, 11, 10. [CrossRef]

58. Deng, Y.Q.; Zhang, N.N.; Li, C.F.; Tian, M.; Hao, J.N.; Xie, X.P.; Shi, P.Y.; Qin, C.F. Adenosine Analog NITD008 Is a Potent Inhibitor of Zika Virus. Open Forum Infect. Dis. 2016, 3. [CrossRef]

59. Yin, Z.; Chen, Y.L.; Schul, W.; Wang, Q.Y.; Gu, F.; Duraiswamy, J.; Kondreddi, R.R.; Niyomrattanakit, P.; Lakshminarayana, S.B.; Goh, A.; et al. An adenosine nucleoside inhibitor of dengue virus. Proc. Natl. Acad. Sci. USA 2009, 106, 20435-20439. [CrossRef]

60. Chen, Y.L.; Yin, Z.; Lakshminarayana, S.B.; Qing, M.; Schul, W.; Duraiswamy, J.; Kondreddi, R.R.; Goh, A.; Xu, H.Y.; Yip, A.; et al. Inhibition of dengue virus by an ester prodrug of an adenosine analog. Antimicrob. Agents Chemother. 2010, 54, 3255-3261. [CrossRef]

61. Hitakarun, A.; Khongwichit, S.; Wikan, N.; Roytrakul, S.; Yoksan, S.; Rajakam, S.; Davidson, A.D.; Smith, D.R. Evaluation of the antiviral activity of orlistat (tetrahydrolipstatin) against dengue virus, Japanese encephalitis virus, Zika virus and chikungunya virus. Sci. Rep. 2020, 10, 1-11. [CrossRef]

62. Tongluan, N.; Ramphan, S.; Wintachai, P.; Jaresitthikunchai, J.; Khongwichit, S.; Wikan, N.; Rajakam, S.; Yoksan, S.; Wongsiriroj, N.; Roytrakul, S.; et al. Involvement of fatty acid synthase in dengue virus infection. Virol. J. 2017, 14, 1-18. [CrossRef] [PubMed]

63. Meutiawati, F.; Bezemer, B.; Strating, J.; Overheul, G.J.; Zusinaite, E.; van Kuppeveld, F.J.M.; van Cleef, K.W.R.; van Rij, R.P. Posaconazole inhibits dengue virus replication by targeting oxysterol-binding protein. Antivir. Res. 2018, 157, 68-79. [CrossRef] [PubMed]

64. Julander, J.G.; Shafer, K.; Smee, D.F.; Morrey, J.D.; Furuta, Y. Activity of T-705 in a hamster model of yellow fever virus infection in comparison with that of a chemically related compound, T-1106. Antimicrob. Agents Chemother. 2009, 53, 202-209. [CrossRef] [PubMed]

65. Koff, W.C.; Elm, J.L., Jr.; Halstead, S.B. Antiviral effects if ribavirin and 6-mercapto-9-tetrahydro-2-furylpurine against dengue viruses in vitro. Antivir. Res. 1982, 2,69-79. [CrossRef]

66. Morrey, J.D.; Smee, D.F.; Sidwell, R.W.; Tseng, C. Identification of active antiviral compounds against a New York isolate of West Nile virus. Antivir. Res. 2002, 55, 107-116. [CrossRef]

67. Rothan, H.A.; Bahrani, H.; Mohamed, Z.; Teoh, T.C.; Shankar, E.M.; Rahman, N.A.; Yusof, R. A Combination of Doxycycline and Ribavirin Alleviated Chikungunya Infection. PLoS ONE 2015, 10, e0126360. [CrossRef]

68. Diosa-Toro, M.; Troost, B.; van de Pol, D.; Heberle, A.M.; Urcuqui-Inchima, S.; Thedieck, K.; Smit, J.M. Tomatidine, a novel antiviral compound towards dengue virus. Antivir. Res. 2019, 161, 90-99. [CrossRef]

69. Troost, B.; Mulder, L.M.; Diosa-Toro, M.; van de Pol, D.; Rodenhuis-Zybert, I.A.; Smit, J.M. Tomatidine, a natural steroidal alkaloid shows antiviral activity towards chikungunya virus in vitro. Sci. Rep. 2020, 10, 1-12. [CrossRef]

70. Sessions, O.M.; Barrows, N.J.; Souza-Neto, J.A.; Robinson, T.J.; Hershey, C.L.; Rodgers, M.A.; Ramirez, J.L.; Dimopoulos, G.; Yang, P.L.; Pearson, J.L.; et al. Discovery of insect and human dengue virus host factors. Nature 2009, 458, 1047-1050. [CrossRef]

71. Filone, C.M.; Hanna, S.L.; Caino, M.C.; Bambina, S.; Doms, R.W.; Cherry, S. Rift valley fever virus infection of human cells and insect hosts is promoted by protein kinase C epsilon. PLOS ONE 2010, 5, e15483. [CrossRef]

72. Mosso, C.; Galvan-Mendoza, I.J.; Ludert, J.E.; del Angel, R.M. Endocytic pathway followed by dengue virus to infect the mosquito cell line C6/36 HT. Virology 2008, 378, 193-199. [CrossRef] [PubMed]

73. Mukhopadhyay, S.; Kuhn, R.J.; Rossmann, M.G. A structural perspective of the Flavivirus life cycle. Nat. Rev. Microbiol. 2005, 3, 13-22. [CrossRef] [PubMed]

74. Cruz-Oliveira, C.; Freire, J.M.; Conceicao, T.M.; Higa, L.M.; Castanho, M.A.R.B.; Da Poian, A.T. Receptors and routes of dengue virus entry into the host cells. FEMS Microbiol. Rev. 2015, 39, 155-170. [CrossRef]

75. Chu, J.J.H.; Leong, P.W.H.; Ng, M.L. Analysis of the endocytic pathway mediating the infectious entry of mosquito-borne flavivirus West Nile into Aedes albopictus mosquito (C6/36) cells. Virology 2006, 349, 463-475. [CrossRef] [PubMed]

76. Acosta, E.G.; Castilla, V.; Damonte, E.B. Infectious dengue-1 virus entry into mosquito C6/36 cells. Virus Res. 2011, 160, 173-179. [CrossRef]

77. Acosta, E.G.; Castilla, V.; Damonte, E.B. Functional entry of dengue virus into Aedes albopictus mosquito cells is dependent on clathrinmediated endocytosis. J. Gen. Virol. 2008, 89, 474-484. [CrossRef]

78. Baer, A.; Shafagati, N.; Benedict, A.; Ammosova, T.; Ivanov, A.; Hakami, R.M.; Terasaki, K.; Makino, S.; Nekhai, S.; Kehn-Hall, K. Protein Phosphatase-1 regulates Rift Valley fever virus replication. Antivir. Res. 2016, 127, 79-89. [CrossRef] 
79. Lani, R.; Hassandarvish, P.; Shu, M.H.; Phoon, W.H.; Chu, J.J.; Higgs, S.; Vanlandingham, D.; Abu Bakar, S.; Zandi, K. Antiviral activity of selected flavonoids against Chikungunya virus. Antivir. Res. 2016, 133, 50-61. [CrossRef]

80. Liu, W.J.; Aaskov, J.G. Fitness peaks of dengue virus populations. PLoS ONE 2018, 13, e0189554. [CrossRef]

81. Nawa, M. Effects of bafilomycin A1 on Japanese encephalitis virus in C6/36 mosquito cells. Arch. Virol. 1998, 143, 1555-1568. [CrossRef]

82. Guo, F.; Wu, S.; Julander, J.; Ma, J.; Zhang, X.; Kulp, J.; Cuconati, A.; Block, T.M.; Du, Y.; Guo, J.T.; et al. A Novel Benzodiazepine Compound Inhibits Yellow Fever Virus Infection by Specifically Targeting NS4B Protein. J. Virol. 2016, 90, 10774-10788. [CrossRef] [PubMed]

83. Xin, Q.L.; Deng, C.L.; Chen, X.; Wang, J.; Wang, S.B.; Wang, W.; Deng, F.; Zhang, B.; Xiao, G.; Zhang, L.K. Quantitative Proteomic Analysis of Mosquito C6/36 Cells Reveals Host Proteins Involved in Zika Virus Infection. J. Virol. 2017, 91, e00554-17. [CrossRef] [PubMed]

84. Talarico, L.B.; Noseda, M.D.; Ducatti, D.R.B.; Duarte, M.E.R.; Damonte, E.B. Differential inhibition of dengue virus infection in mammalian and mosquito cells by iota-carrageenan. J. Gen. Virol. 2011, 92, 1332-1342. [CrossRef] [PubMed]

85. Talarico, L.B.; Damonte, E.B. Interference in dengue virus adsorption and uncoating by carrageenans. Virology 2007, 363, 473-485. [CrossRef]

86. Qiu, H.; Tang, W.; Tong, X.K.; Ding, K.; Zuo, J.P. Structure elucidation and sulfated derivatives preparation of two alpha-D-glucans from Gastrodia elata Bl. and their anti-dengue virus bioactivities. Carbohyd Res. 2007, 342, 2230-2236. [CrossRef]

87. Pujol, C.A.; Estevez, J.M.; Carlucci, M.J.; Ciancia, M.; Cerezo, A.S.; Damonte, E.B. Novel DL-galactan hybrids from the red seaweed Gymnogongrus torulosus are potent inhibitors of herpes simplex virus and dengue virus. Antivir. Chem. Chemother. 2002, 13, 83-89. [CrossRef]

88. Lin, Y.L.; Lei, H.Y.; Lin, Y.S.; Yeh, T.M.; Chen, S.H.; Liu, H.S. Heparin inhibits dengue-2 virus infection of five human liver cell lines. Antivir. Res. 2002, 56, 93-96. [CrossRef]

89. Talarico, L.B.; Pujol, C.A.; Zibetti, R.G.M.; Faria, P.C.S.; Noseda, M.D.; Duarte, M.E.R.; Damonte, E.B. The antiviral activity of sulfated polysaccharides against dengue virus is dependent on virus serotype and host cell. Antivir. Res. 2005, 66, 103-110. [CrossRef]

90. Thaisomboonsuk, B.K.; Clayson, E.T.; Pantuwatana, S.; Vaughn, D.W.; Endy, T.P. Characterization of dengue-2 virus binding to surfaces of mammalian and insect cells. Am. J. Trop. Med. Hyg. 2005, 72, 375-383. [CrossRef]

91. Chaccour, C.; Lines, J.; Whitty, C.J. Effect of ivermectin on Anopheles gambiae mosquitoes fed on humans: The potential of oral insecticides in malaria control. J. Infect. Dis. 2010, 202, 113-116. [CrossRef] [PubMed]

92. Deus, K.M.; Saavedra-Rodriguez, K.; Butters, M.P.; Black, W.C.; Foy, B.D. The effect of ivermectin in seven strains of Aedes aegypti (Diptera: Culicidae) including a genetically diverse laboratory strain and three permethrin resistant strains. J. Med. Entomol. 2012, 49, 356-363. [CrossRef]

93. Weiser, J.; Matha, V. The insecticidal activity of cyclosporines on mosquito larvae. J. Invertebr. Pathol. 1988, 51, 92-93. [CrossRef]

94. Dong, S.; Balaraman, V.; Kantor, A.M.; Lin, J.; Grant, D.G.; Held, N.L.; Franz, A.W.E. Chikungunya virus dissemination from the midgut of Aedes aegypti is associated with temporal basal lamina degradation during bloodmeal digestion. PLoS Negl. Trop. Dis. 2017, 11, e0005976. [CrossRef] [PubMed]

95. Sim, S.; Jupatanakul, N.; Dimopoulos, G. Mosquito immunity against arboviruses. Viruses 2014, 6, 4479-4504. [CrossRef] [PubMed]

96. Cheng, G.; Liu, Y.; Wang, P.; Xiao, X. Mosquito Defense Strategies against Viral Infection. Trends Parasitol. 2016, 32, 177-186. [CrossRef] [PubMed]

97. Cirimotich, C.M.; Scott, J.C.; Phillips, A.T.; Geiss, B.J.; Olson, K.E. Suppression of RNA interference increases alphavirus replication and virus-associated mortality in Aedes aegypti mosquitoes. BMC Microbiol. 2009, 9, 49. [CrossRef] [PubMed]

98. Sanchez-Vargas, I.; Scott, J.C.; Poole-Smith, B.K.; Franz, A.W.; Barbosa-Solomieu, V.; Wilusz, J.; Olson, K.E.; Blair, C.D. Dengue virus type 2 infections of Aedes aegypti are modulated by the mosquito's RNA interference pathway. PLoS Pathog. 2009, 5, e1000299. [CrossRef] [PubMed]

99. Souza-Neto, J.A.; Sim, S.; Dimopoulos, G. An evolutionary conserved function of the JAK-STAT pathway in anti-dengue defense. Proc. Natl. Acad. Sci. USA 2009, 106, 17841-17846. [CrossRef] [PubMed]

100. Xi, Z.; Ramirez, J.L.; Dimopoulos, G. The Aedes aegypti toll pathway controls dengue virus infection. PLoS Pathog. 2008, 4, e1000098. [CrossRef]

101. O'Neill, K.; Olson, B.J.; Huang, N.; Unis, D.; Clem, R.J. Rapid selection against arbovirus-induced apoptosis during infection of a mosquito vector. Proc. Natl. Acad. Sci. USA 2015, 112, E1152-E1161. [CrossRef]

102. Vaidyanathan, R.; Scott, T.W. Apoptosis in mosquito midgut epithelia associated with West Nile virus infection. Apoptosis 2006, 11, 1643-1651. [CrossRef] [PubMed]

103. Kuadkitkan, A.; Wikan, N.; Fongsaran, C.; Smith, D.R. Identification and characterization of prohibitin as a receptor protein mediating DENV-2 entry into insect cells. Virology 2010, 406, 149-161. [CrossRef] [PubMed]

104. Sun, P.; Nie, K.; Zhu, Y.; Liu, Y.; Wu, P.; Liu, Z.; Du, S.; Fan, H.; Chen, C.H.; Zhang, R.; et al. A mosquito salivary protein promotes flavivirus transmission by activation of autophagy. Nat. Commun. 2020, 11, 260. [CrossRef] [PubMed]

105. Cheng, G.; Cox, J.; Wang, P.; Krishnan, M.N.; Dai, J.; Qian, F.; Anderson, J.F.; Fikrig, E. A C-type lectin collaborates with a CD45 phosphatase homolog to facilitate West Nile virus infection of mosquitoes. Cell 2010, 142, 714-725. [CrossRef] 
106. Clyde, K.; Kyle, J.L.; Harris, E. Recent advances in deciphering viral and host determinants of dengue virus replication and pathogenesis. J. Virol. 2006, 80, 11418-11431. [CrossRef]

107. Sabino, C.; Basic, M.; Bender, D.; Elgner, F.; Himmelsbach, K.; Hildt, E. Bafilomycin A1 and U18666A Efficiently Impair ZIKV Infection. Viruses 2019, 11, 524. [CrossRef]

108. Hunt, S.R.; Hernandez, R.; Brown, D.T. Role of the vacuolar-ATPase in Sindbis virus infection. J. Virol. 2011, 85, 1257-1266. [CrossRef]

109. Scott-Fiorenzano, J.M.; Fulcher, A.P.; Seeger, K.E.; Allan, S.A.; Kline, D.L.; Koehler, P.G.; Muller, G.C.; Xue, R.D. Evaluations of dual attractant toxic sugar baits for surveillance and control of Aedes aegypti and Aedes albopictus in Florida. Parasites Vectors 2017, 10, 9. [CrossRef]

110. Fiorenzano, J.M.; Koehler, P.G.; Xue, R.D. Attractive Toxic Sugar Bait (ATSB) For Control of Mosquitoes and Its Impact on Non-Target Organisms: A Review. Int. J. Environ. Res. Public Health 2017, 14, 398. [CrossRef]

111. Pryce, J.; Richardson, M.; Lengeler, C. Insecticide-treated nets for preventing malaria. Cochrane Db Syst Rev. 2018. [CrossRef]

112. Kanmiki, E.W.; Awoonor-Williams, J.K.; Phillips, J.F.; Kachur, S.P.; Achana, S.F.; Akazili, J.; Bawah, A.A. Socio-economic and demographic disparities in ownership and use of insecticide- treated bed nets for preventing malaria among rural reproductiveaged women in northern Ghana. PLoS ONE 2019, 14, e0211365. [CrossRef] [PubMed]

113. Lenhart, A.; Morrison, A.C.; Paz-Soldan, V.A.; Forshey, B.M.; Cordova-Lopez, J.J.; Astete, H.; Elder, J.P.; Sihuincha, M.; Gotlieb, E.E.; Halsey, E.S.; et al. The impact of insecticide treated curtains on dengue virus transmission: A cluster randomized trial in Iquitos, Peru. PLoS Negl. Trop. Dis. 2020, 14, e0008097. [CrossRef] [PubMed]

114. Lenhart, A.; Orelus, N.; Maskill, R.; Alexander, N.; Streit, T.; McCall, P.J. Insecticide-treated bednets to control dengue vectors: Preliminary evidence from a controlled trial in Haiti. Trop. Med. Int. Health 2008, 13, 56-67. [CrossRef] [PubMed]

115. Paton, D.G.; Childs, L.M.; Itoe, M.A.; Holmdahl, I.E.; Buckee, C.O.; Catteruccia, F. Exposing Anopheles mosquitoes to antimalarials blocks Plasmodium parasite transmission. Nature 2019, 567, 239-243. [CrossRef] [PubMed] 